DOI $10.32820 / 2079-1747-2020-25-159-167$

UDC 377.112.4:620

\title{
ENERGY WHICH IS CONVERTED BY THE HEAT PUMP AS A MEANS OF REDUCING COSTS FOR HEATING RESIDENTIAL BUILDINGS
}

\author{
CAntonenko N., Hrinchenko H., Kanjuk G., Khomenko V. \\ Украйнська інженерно-педагогічна академія \\ Інформація про авторів
}

Антоненко Наталія Сергіївна: ORCID 0000-0001-5576-3388; nsantonenko2015@gmail.com; кандидат технічних наук; декан факультету Енергетики, енергозберігаючих технологій і автоматизації енергетичних процесів; Українська інженерно-педагогічна академія; вул. Університетська, 16, м. Харків 61007, Україна

Грінченко Ганна Сергї̈вна: ORCID 0000-0002-6498-6142; a.kiporenko@ukr.net; кандидат технічних наук; доцент кафедри охорони праці, стандартизації та сертифікації; Українська інженерно-педагогічна академія; вул. Університетська, 16, м. Харків 61007, Україна

Канюк Генадій Іванович: ORCID 0000-0003-1399-9039; art-studio diana aukr.net; доктор технічних наук; завідувач кафедри теплоенергетики та енергозберігаючих технологій; Українска інженерно-педагогічна академія; вул. Університетська, 16, м. Харків 61007, Україна

Хоменко Віктор Віталійович: ORCID 0000-0002-9826-1123; homenkoviktor1990@gmail.com; кандидат технічних наук; доцент кафедри теплоенергетики та енергозберігаючих технологій; Українська інженернопедагогічна академія; вул. Університетська, 16, м. Харків 61007, Україна

The concept of optimizing heating costs for a separate residential building at the expense of supplying the energy transformed by the heat pump to the home and the changes in the heat energy losses everywhere external walls is presented in this work.

The main purpose of the article is to determine the rational modes of operation of the heat pump, on the condition that there is compensation for the cost of heat through the walls of the building. This allows to adjust the heating costs of the building through the use of a heat pump, reducing the coefficient of thermal conductivity of the material of the walls of the house and saving electricity. Electricity savings result from reducing the heat pump's operation and reducing heat loss through the walls of a residential building. Calculation of thermal energy losses through the walls was carried out on the basis of calculations of tabular data and research on the operation of the heat pump, which were carried out on the basis of the physical model of the thermal installation. In assessing the economic efficiency of the heat pump it takes into account the difference in size of market rates for equivalent amounts of electricity and heat as the heat pump to work consumes electricity and useful thermal energy is consumed. With the integrated use of the heat pump and a $41.5 \%$ reduction in the coefficient of thermal conductivity of the material of the walls of the building, it will allow an additional $43.5 \%$ increase in the cost of heating.

Keywords: energy of heat pump, heating of a residential building, cost savings.

Антоненко Н.С., Грінченко Г.С., Канюк Г.І., Хоменко В.В. «Енергія, перетворена тепловим насосом, як засіб зменшення витрат на опалення житлової будівлі».

В роботі представлена концепція оптимізації витрат на опалення для окремої житлової будівлі за рахунок постачання в оселю енергії перетвореної тепловим насосом та змін втрат теплової енергії скрізь зовнішні стіни. Основна мета статті полягає у визначенні раціональних режимів роботи теплового насосу при умові, що $є$ компенсація витрат тепла крізь стіни будівлі.

Це дає змогу регулювати витрати на опалення будівлі за рахунок застосування теплового насосу, зменшення коефіцієнту теплопровідності матеріалу стін будинку та економії електричної енергії. Економія електричної енергії виникає за рахунок скорочення роботи теплового насосу та зменшення втрат тепла крізь стіни житлового будинку. Розрахунок втрат теплової енергії крізь стіни здійснювався на основі розрахунків табличних даних та дослідження роботи теплового насосу, які були проведені на базі фізичної моделі теплової установки. При оцінці економічної ефективності роботи теплового насосу враховується різниця у величині ринкових тарифів на еквівалентні об'єми електричної і теплової енергії, оскільки на 
роботу теплового насосу витрачається електроенергія, а корисно спожитою енергією є теплова. При комплексному використанні теплового насосу та зменшенні на 41,5\% коефіцієнту теплопровідності матеріалу стін будівлі, дозволятиме додатково на 43,5\% підвищити економію витрат на опалення.

Ключові слова: енергія теплового насосу, отоплення жилової будівлі, економія витрат.

Антоненко Н.С., Гринченко А.С., Канюк Г.И., Хоменко В.В. «Энергия, превращенная тепловым насосом, как средство уменьшения затрат на отопление жилого здания».

В работе представлена концепция оптимизации затрат на отопление для отдельного жилого здания за счет поставок в дом энергии преобразованной тепловым насосом и изменений потерь тепловой энергии наружных стен. Основная цель статьи заключается в определении рациональных режимов работы теплового насоса при условии, что есть компенсация расходов тепла через стены здания. Это позволяет регулировать затраты на отопление здания за счет применения теплового насоса, уменьшение коэффициента теплопроводности материала стен дома и экономии электроэнергии. Экономия электрической энергии возникает за счет сокращения работы теплового насоса и уменьшение потерь тепла через стены жилого дома. Расчет потерь тепловой энергии через стены осуществлялся на основе расчетов табличных данных и исследования работы теплового насоса, которые были проведены на базе физической модели тепловой установки. При оценке экономической эффективности работы теплового насоса учитывается разница в величине рыночных тарифов на эквивалентные объемы электрической и тепловой энергии, поскольку на работу теплового насоса расходуется электроэнергия, а полезно потребленной энергией является тепловая. При комплексном использовании теплового насоса и уменьшении на 41,5\% коэффициента теплопроводности материала стен здания, позволит дополнительно на 43,5\% повысить экономию расходов на отопление.

Ключевые слова: энергия теплового насоса, отопление жилого здания, экономия затрат.

\section{Introduction}

Energy independence of the state is one of the indispensable conditions for the effective functioning of all spheres of the country's economy. Reducing the energy intensity of production is achieved by a set of measures for energy and resource conservation, namely, the system interbranch approach. Reducing the cost of heating a residential building is based on the following principles: heating the room through the use of heat pumps; the performance of a heat pump, which is determined on the basis of compensation of heat energy costs everywhere in the walls of the house; selection of material and structure of the walls of the building in order to ensure rational heat loss through in the walls of the building [1].

\section{Purpose of the article}

The main purpose of this article is to use the heating of the room with the help of a heat pump, and the rational mode of its work is determined taking into account the cost of heat through the walls of the building, and can be expressed in the following form:

$$
Q_{B}=Q_{H}-Q_{C T}
$$

where $Q_{\mathrm{b}}$ is the total amount of thermal energy in the building, $\mathrm{kJ} ; Q_{\mathrm{H}}$ is the power of the heat pump operation $\mathrm{kJ} / \mathrm{h} ; Q_{\mathrm{H}}$ is the power consumption of heat through the walls of the building, $\mathrm{kJh} / \mathrm{m}^{2}$.

To achieve the goal, it is needed to solve the following tasks:

1. Apply the heating of the building with the help of a heat pump; 
2. Determine the performance of a heat pump based on the cost of heat through the outer walls of the building;

3. Determine the role of the material of the walls of the building in order to optimize the heating costs of the building.

\section{Analysis of recent research and publications}

One of the perspective directions of the development of heat supply systems for housing and communal services is the use of heat pumps (HP). The essence of the work is the transformation of the thermal energy of the earth, groundwater, air, which characterize the temperature of the earth, groundwater, air to the temperature $\left(45 \ldots 75^{\circ} \mathrm{C}\right)$, which is used in the heating system [2]

HP manufacturers assure the economic efficiency of the operation of such plants and provide comparative data consumed by the pump of electricity and transport thermal energy. At the same time, the ratio of these components corresponds as 1 to $3-5$, which undoubtedly speaks about the expediency of mass use of installations of this type. This led to the urgent need to study the effectiveness of the use of HP [3]

\section{The main material research}

The theoretical basis of the work of HP (the principle of which is based on the reverse cycle Carno) is sufficiently detailed in the scientific literature on the basis of heat engineering and heat transformation, and the practical design of this type of power equipment depending on the working environment and the company has a number of features and differences that and determines the area of its use, working conditions, energy and economic efficiency. The heat pumps have been given a lot of attention by leading specialists, such as designers, manufacturers and operating personnel, in recent years [4]. This determined the need to form the relevant knowledge and skills of a wide range of specialists working in the field of energy supply and energy saving, as well as in related industries. On the Fig. 1 it is presented the basic scheme of installation of HP. The principle of the effect of HP is that it (HP) takes heat energy from one place, carries (pumping) it, and gives it to another place. While the principle of heating geothermal HP is based on the collection of heat from the environment surrounding the building, and transmits the heat collected to the heating system (or hot water supply) of the building.

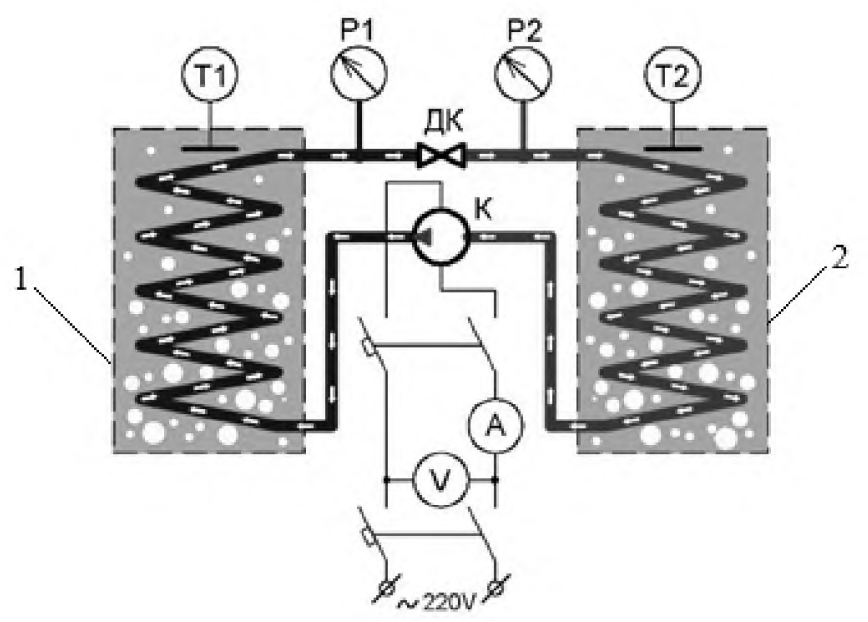

Fig. 1 Principal scheme of the heat pump [5] 
As it can be seen from Fig. 1. the circuit diagram of the heat pump operation includes three closed circuits. In the first, external, circulates the heat transfer fluid $\mathrm{C} 1$ (the medium of the heat source directly or the heat carrier, which accumulates it). The second circuit circulates the refrigerant (a substance that evaporates, removing the heat of the heat sink, and condenses, giving the heat to the heat-receiver). In this circuit, there is an evaporator 1 , a condenser 2, representing heat exchangers with medium $\mathrm{C} 1$ and $\mathrm{C} 2$, respectively, a compressor $\mathrm{K}$, designed to create a coolant circulation in the second circuit, a throttle valve (TV) in which the change in the aggregate state of the refrigerant occurs. In the third - heat receiver (as a rule, water in heating systems and hot water supply of industrial or communal household heat supply).

In real technological systems of geothermal HP, the outer contour is produced more often in the form of a horizontal or vertical pipeline, enclosed in the ground or in water, in which the nonfreezing liquid/ antifreeze circulates. The second circuit is an integral part of the technological installation of HP, which contains, in addition to two heat exchangers, a compressor and a throttle valve control system and emergency automatics, a system of power supply, accounting and control devices. The third circuit is the inner circuit, that is, the system of building heating itself or a system of hot water supply.

The heat pump's cycle repeats the Carno cycle [6] in reverse order. Liquid refrigerant is forced through a throttle, its pressure drops, and it enters the evaporator, where it boils, selecting the heat supplied by the collector from the environment. The gas to which the refrigerant has been converted is absorbed into the compressor and compressed and a heated one is pushed into a condenser. The condenser is a heat pump unit that gives heat: here heat is received by water in the system of the heating circuit. At the same time, the gas is cooled and condensed to again discharge into the expansion valve and return to the evaporator. After that, the work cycle starts again.

The cycle system from the thermostat with a lower temperature $T_{2}$ subtracts the amount of heat $\mathrm{Q}_{2}$ and is given to the thermostat with a higher temperature $\mathrm{T}_{1}$ the amount of heat $\mathrm{Q}_{1}$. For a circular process, $\mathrm{Q}=\mathrm{A}$, but, $\mathrm{Q}=\mathrm{Q}_{2}-\mathrm{Q}_{1}<0$, therefore $\mathrm{A}<0$ i $\mathrm{Q}_{2}-\mathrm{Q}_{1}=-\mathrm{A}$, or $\mathrm{Q}_{1}=\mathrm{Q}_{2}+\mathrm{A}$, that is, the amount of heat $Q_{1}$, which is given by the system of heat source at the higher temperature $T_{1}$ is greater than the amount of heat $\mathrm{Q}_{2}$, which is received from the heat source at a lower temperature $\mathrm{T}_{2}$, by the amount of work carried out over the system. Consequently, without the work it is impossible to select heat from the less heated body and give it more heated. This statement is nothing more than the second beginning of thermodynamics in the formulation of Clausius. Proceeding from this it can be argued that the efficiency of the heat pump directly depends on the efficiency factor (EF) of the Carno cycle of a specific heat engineering installation. In other words, the ratio of the summed mechanical energy consumed to pump the coolant and change its aggregate state and pumped heat energy, which determines the efficiency of the HP, depends on the efficiency of the cycle of the HP operation. This correlation can not be called efficiency factor, therefore it is often called the "transformation coefficient" of HP, which is determined by the formula:

$$
K_{T m u}=\frac{W_{m}}{W_{9 n}}=\frac{Q_{m}}{Q_{э n}}
$$

where $Q_{\mathrm{el}}, W_{\mathrm{el}}$ is thermal or active electric energy correspondingly to the work of the compressor, $\mathrm{kWt} / \mathrm{h} . Q_{\mathrm{t}}, W_{\mathrm{T}}$ is thermal or equivalent thermal energy, which is given in the unit of measurement of 
electricity, respectively, obtained at the output of the condenser, J. For the most part of industrial production, this coefficient ranges from 3 to 5 in the energy equivalent. However, in assessing the economic efficiency of HP work, account should be taken of the difference in the size of market tariffs at the equivalent volume of electrical and thermal energy, since the work of HP consumes electricity, and the energy consumed is heat. Therefore, calculating the energy efficiency of the same HP in the electrical and thermal equivalents, and multiplying the corresponding market tariffs, these types of energy will have different indicators. Therefore, economic efficiency should be determined taking into account the existing tariffs for heat and electricity in a particular region.

The physical meaning of energy conversion is explained in the following way. Let's imagine that in the capacity of $\mathrm{C}_{1}$ and $\mathrm{C}_{2}$ water was filled with the same temperature. After that we turn on a compressor that pumps the coolant of the second circuit, which leads to the cooling of the evaporator 1 and the heating of the condenser 2 .

As a result, the water temperature in the containers will vary in proportion to the amount of pumped heat from the medium $C_{1}$ (water vaporizer volume) to the medium $C_{2}$ (water of the condenser). Knowing the temperature variation of each medium $\Delta \mathrm{t}$ we can determine the amount of heat $Q$ transported from medium 1 to medium 3 according to the formula:

$$
Q=m \cdot C \cdot \Delta t
$$

where $\mathrm{m}$ is mass of coolant, $\mathrm{kg}$; $C$ is heat capacity of the coolant (for water $4170 \mathrm{~J} / \mathrm{kgK}$ ); $\Delta \mathrm{t}$ is the value change of temperature, $\mathrm{K}$.

If we carry out measurements with a certain time interval (testing the stand the interval was taken equal to $2 \mathrm{~min}$ ), then we obtain data on the dynamics of temperature changes of media, the pressure of the coolant in the evaporator and the condenser consumed by the electric power compressor and calculate the economic efficiency of the heat pump according to the formula:

$$
\ni=Q_{K} \cdot C_{m \ni}-W_{K} \cdot C_{\ni э}
$$

where $Q_{\mathrm{c}}$ is the heat energy is transmitted from the condenser to the medium $C_{2}, \mathrm{~kJ}$; $C_{\mathrm{he}}$ is a commercial tariff for heat energy in a particular region for a particular consumer, $\mathrm{UAH} \mathrm{kJ} ; W_{A}$ is the amount of electricity consumed by the compressor $\mathrm{HP}, \mathrm{kW} \mathrm{h} ; C_{c t}$ - commercial tariff for electricity in a specific region for a particular consumer, UAH $\mathrm{kWh}$. Chart changes in the main values for the 20 -minute cycle of the stand are shown on Fig. 2.

In fig. 2nd shows the change in temperature in the media $\mathrm{C} 1$ and $\mathrm{C} 2$ during the first 20 minutes of TN. In fig. 2-b shows a change in excess pressure P1 and P2, MPa. Figure 2-c shows the dynamics of the rate of growth of temperature in the media $\mathrm{C} 1$ and $\mathrm{C} 2$. In fig. 2-d represents the dynamics of economic efficiency growth in the first twenty minutes of the work of TN. Based on the principle of the operation of the HP and the basic laws of heat engineering in the laboratory, the process of operation of the HP was modeled, as well as its main technical indicators were obtained, which allowed to determine the economic efficiency of the operation of this type of energy-saving equipment. The considered booth is universal and can be further used to work in simulation models of complex systems of power supply and energy saving. In the tests carried out on the physical model of HP economic efficiency was achieved in the amount of $0.46 \mathrm{UAH}$ within 20 minutes, which, in terms of the daily time interval, will amount to $33.12 \mathrm{UAH}$, and in recalculation for the time of the annual heating season will be $6044.5 \mathrm{UAH}$. 


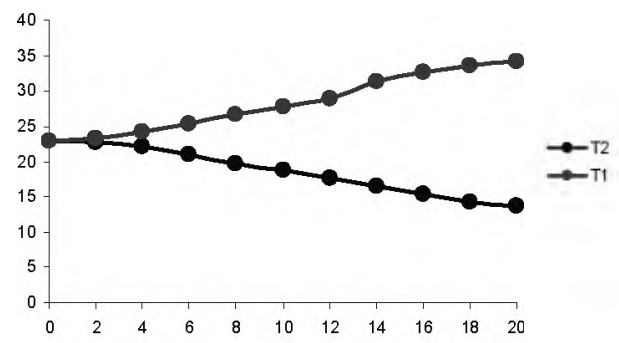

A

$\Delta \mathrm{T}$

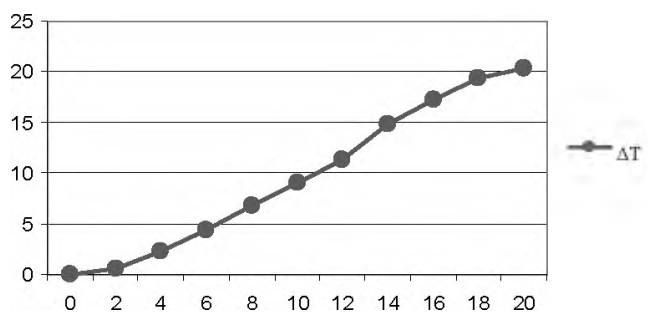

$\mathrm{C}$

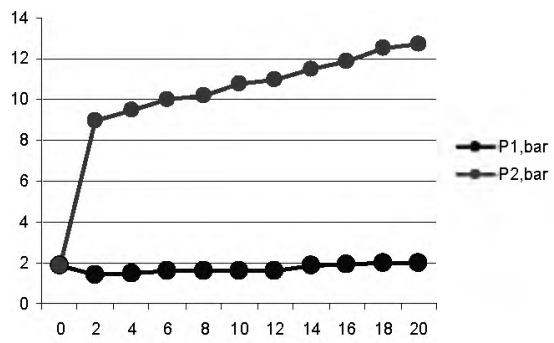

B

Прибыль, грн

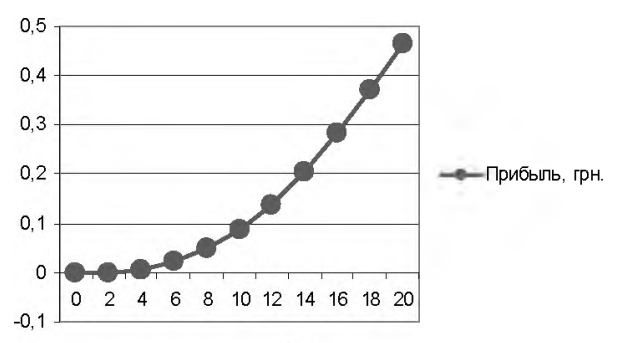

$\mathrm{D}$

Fig. 2 Changing the main parameters of the heat pump in operating mode

Determination of operating modes of the heat pump based on the calculation of thermal energy losses through the walls of a residential building

The choice of material for the walls of the building is more important stage in its design. Throughout the walls of the building is constantly lost thermal energy, which should be replenished at the expense of electricity consumption. For example, we estimate the scale of thermal energy loss though the outer walls for a two-storey house of $12 \times 12 \mathrm{~m}$. The area of the external walls for this building at a height of the building of $2.5 \mathrm{~m}$ will be $240 \mathrm{~m}^{2}$. The thickness of the walls of brick with a standard thickness of $0.8 \mathrm{~m}$.

The amount of thermal energy passing through a wall of thickness $L$ is determined by the formula:

$$
Q=\lambda \cdot \frac{T_{1}-T_{2}}{L} \cdot S
$$

Where $\lambda$ is a coefficient of thermal conductivity $\left[\mathrm{Wt} /\left(\mathrm{m}{ }^{\circ} \mathrm{C}\right)\right] ; L$ is the wall thickness, $\mathrm{m}$; $T_{1}-T_{2}$ is a gradient between the temperatures on the outer and inner surfaces of the wall, ${ }^{\circ} \mathrm{C} ; S=$ $b \times h$ is area of the wall (without windows), $\mathrm{m}^{2}$.

Determine the amount of heat that is lost through the wall under two conditions, in the first case, that the wall consists of one material $\lambda=0,44 \mathrm{Wt} / \mathrm{m}^{\circ} \mathrm{C}$, in the second case, that the wall consists of one material from two materials $66,7 \%$ the thickness of the wall of the material with $\lambda=$ $0,44 \mathrm{Wt} / \mathrm{m}^{\circ} \mathrm{C}$, and $33,3 \%$ the thickness of the wall of the material with $\lambda=0,15 \mathrm{Wt} / \mathrm{m}^{\circ} \mathrm{C}$. The temperature gradient is equal to $20^{\circ} \mathrm{C}$, but the area of the walls of the building $=S=240 \mathrm{~m}^{2}$.

Determination of heat loss everywhere external walls at different values of the coefficient of thermal conductivity of their material. The balance of heat consumption of the equivalent of electric energy in all positions per hour is given in the table.

In tabl. 2 shows the calculation of the cost of heating the building with the change in the cost of heat everywhere external walls in the change in the coefficient of thermal conductivity of the material walls. 
Table 1.

\begin{tabular}{|c|c|c|c|c|}
\hline № & $\begin{array}{c}\text { Thickness of the } \\
\text { wall, } \\
\mathrm{L}, \mathbf{m}\end{array}$ & $\lambda$ & $\begin{array}{c}\text { Specific, amount of heat per } \mathbf{m}^{2} \\
\text { wall area, } \mathrm{Q}[\mathrm{kWh}]\end{array}$ & $\begin{array}{c}\text { Loss of heat through the } \\
\text { walls, } \mathrm{kWh}\end{array}$ \\
\hline 1 & 0,8 & 0,44 & 0,022 & 2,64 \\
\hline 2 & 0,5 & 0,44 & 0,01425 & 1,71 \\
\cline { 2 - 3 } & 0,25 & 0,15 & & \\
\hline
\end{tabular}

Table 2 .

\begin{tabular}{|c|c|c|c|c|c|c|}
\hline № & $\begin{array}{c}\text { Costs heat } \\
\text { through } \\
\text { the walls, } \\
\mathrm{kWh} \\
\text { equivalent } \\
\text { costs } \\
\text { through the } \\
\text { wall, UAH }\end{array}$ & $\begin{array}{c}\text { Atmosphere of } \\
\text { thermal energy } \\
\text { from HP, kWh }\end{array}$ & $\begin{array}{c}\text { Cash } \\
\text { expenses } \\
\text { equivalent to } \\
\text { the } \\
\text { extraction of } \\
\text { thermal } \\
\text { energy from } \\
\text { HP, UAH / } \\
\text { year }\end{array}$ & $\begin{array}{c}\text { Money savings } \\
\text { per hour using } \\
\text { HP }\end{array}$ & $\begin{array}{c}\text { savings during the } \\
\text { heating season } \\
\text { from the use of a } \\
\text { heat pump, UAH }\end{array}$ \\
\hline 1 & $-2,64$ & 4,43 & 2,64 & 3,05 & 1,38 & 6044,5 \\
\hline 2 & $-1,71$ & 2,87 & 1,71 & 1,97 & 0,9 & 3942,0 \\
\hline
\end{tabular}

From the table it follows, on the one hand, that with a decrease in the cost of electric energy by a heat pump, savings from 6044.5 to $3942.0 \mathrm{UAH}$ are reduced. However, on the other hand, it is necessary to take into account the fact that in the second option, we further save on reducing the cost of electricity from 3.05 to 1.97 UAH. During the heating season it is 4730,4 .

The result of all savings will be 8672,4 UAH. That is, at reducing the cost of heat energy everywhere through the reduction of the coefficient of their thermal conductivity, we get a total savings of $8672.4 \mathrm{UAH}$.

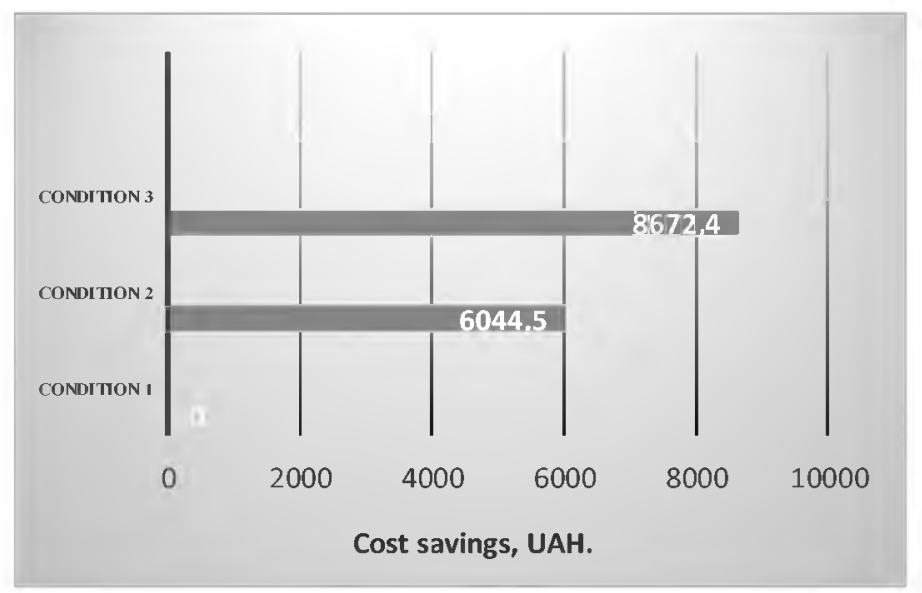

Fig. 3 Determination of cost savings for heating 
Figure 3 shows a diagram for determining the cost savings for heating. The diagram is based on three conditions:

1. Calculate the basic costs of electric energy (without the use of a heat pump) for the development of heat energy, which maintains the required amount of heat in the building and compensates for the heat flow through the external walls of the building (the walls of the building have a coefficient of thermal conductivity which is equal to $0.44\left[\mathrm{~W} / \mathrm{m}^{\circ} \mathrm{C}\right]$;

2. The cost savings for heating when using a heat pump are calculated. The heat pump generates thermal energy that maintains the required amount of heat in the building and compensates for the heat losses everywhere outside the walls of the building (the walls of the building have a thermal conductivity coefficient equal to $0.44\left[\mathrm{~W} / \mathrm{m}^{\circ} \mathrm{C}\right]$;

3. Calculation of heating costs using a heat pump when changing the thermal conductivity coefficient $(\lambda)$, the material of the walls of the building, which is equal to $\lambda=0,44\left[\mathrm{~W} / \mathrm{m}^{\circ} \mathrm{C}\right]$. The laying of the walls varies: in the section of the outer wall, instead of three bricks of $0.25 \mathrm{~m}$ with $\lambda=0,44$ laid out two rows of bricks with $\lambda=0,44$, and the average number of bricks with a coefficient of thermal conductivity $\lambda=0,15$ ( see tabl. 1). The final coefficient of thermal conductivity of the wall is obtained by the equation:

$$
\lambda=0,5 \cdot 0,44+0,25 \cdot 0,15=0,2575,\left[\mathrm{~W} / \mathrm{m}^{\circ} \mathrm{C}\right]
$$

Thus, the third condition is that we use a heat pump, the wall has a coefficient of thermal conductivity $\lambda=0,2575\left[\mathrm{BT} / \mathrm{M}^{0} \mathrm{C}\right]$. This leads to the fact that, in order to compensate for the loss of heat through the wall of the thermal energy in the building will be less, so we get a lower savings of 3942.0 UAH for the heating season, instead of 6044.5 UAH. Determine the energy savings (at a tariff of $1.68 \mathrm{UAH} / \mathrm{kWh}$ ) due to the fact that $\mathrm{HP}$ spent $1.97 \mathrm{UAH}$ instead of $3,05 \mathrm{UAH}$ to compensate heat heat through the wall. We receive for the heating season savings of 4730,4 UAH. The result is an economy of 8672.4 UAH. (Condition 3, Figure 3).

\section{Conclusions}

Thus, on the basis of the study we obtained the following conclusions:

- The general concept of compensation of heat energy losses lost by the walls of the building through the use of a heat pump.

- The estimation shows the economic efficiency of the operation of the heat pump, taking into account the difference in the size of market tariffs for the equivalent volumes of electrical and thermal energy, since the heat pump consumes electricity, and the energy consumed is heat.

- It was established that the main condition for reducing the heating costs of a building is the amount of lost heat energy, and it affects the amount of the lost heat and load coefficient of the material of the walls.

- It was shown that with the use of a heat pump, savings were received during the heating season in the amount of $6044.5 \mathrm{UAH}$. With the integrated use of the heat pump and $41.5 \%$ decrease in the thermal conductivity of the material of the walls in the building, we receive an additional $43.5 \%$ increasing in the cost savings for heating. 


\section{References}

1. Мельник Л.В., Мельник Л.В., Пашечко О.А. Порівняльний аналіз забезпеченості енергетичними ресурсами регіону. Природокористувания та ресурсозбереження. 2013. №4. С. 263-272.

2. Гусаров В.А., Харченко В.В., Сычев А.О. Автономные системы теплоснабжения на основе тепловых насосов воздух-вода. Енергетика і автоматика. 2013. №3. С. 67-71.

3. Счастний Є.Є., Смірнова А.В. Перспективи використання теплових насосів при модернізації системи теплопостачання громадської будівлі. Збірник наукових пращь УкрдАЗТ. 2012. №128. С. $276-282$.

4. Бондарь В.П. Условия минимального прироста энтропии в эквивалентных циклах Карно. Энерготехнологии и ресурсосбережение. 2015. № 5-6. С. 63-74.

5. Чиркин Н.Б., Шерстов Е.В., Клепанда А.С., Несвитайло В.А. Некоторые особенности проектирования и эксплуатации теплонасосных систем теплохладоснабжения часть 1. о требуемой тепловой нагрузке системы и мощности теплового насоса. Энергосбережение. 2010. №6. С. 27-36.

6. Гранкіна В.В., Щербонос Ю.Д. Вплив температури конденсації та пароутворення робочого тіла на коефіцієнт перетворення теплового насосу. Містобудувания та територіальне планувания. 2012. №45. С. 233239.

\section{References}

1. Mel'nik L.V., Mel'nik L.V., Pashechko O.A. Porivnyal'nij analiz zabezpechenosti energetichnimi resursami regionu. Prirodokoristuvannya ta resursozberezhennya. 2013. No 4. Pp. 263-272. (Ukr).

2. Gusarov V.A., Harchenko V.V., Sychev A.O. Avtonomnye sistemy teplosnabzheniya na osnove teplovyh nasosov vozduh-voda. Energetika i avtomatika. 2013. No 3. Pp. 67-71. (Rus).

3. Schastnij E.C., Smirnova A.V. Perspektivi vikoristannya teplovih nasosiv pri modernizaciï sistemi teplopostachannya gromads'koï budivli. Zbirnik naukovih prac' UkrDAZT. 2012. No 128. Pp. 276-282. (Ukr)

4. Bondar' V.P. Usloviya minimal'nogo prirosta ehntropii v ehkvivalentnyh ciklah Karno. Ehnergotekhnologii $i$ resursosberezhenie. 2015. No 5-6. Pp. 63-74. (Rus).

5. Chirkin N.B., SHerstov E.V., Klepanda A.S., Nesvitajlo V.A. Nekotorye osobennosti proektirovaniya i ehkspluatacii teplonasosnyh sistem teplohladosnabzheniya chast' 1 . o trebuemoj teplovoj nagruzke sistemy i moshchnosti teplovogo nasosa. Ehnergosberezhenie. 2010. No 6. Pp. 27-36. (Rus).

6. Grankina V.V., Shcherbonos Yu.D. Vpliv temperaturi kondensaciï ta paroutvorennya robochogo tila na koeficient peretvorennya teplovogo nasosu. Mistobuduvannya ta teritorial'ne plamuvannya. 2012. No 45. Pp. $233-239$. (Ukr).

The article was received on March 19, 2020. 